\title{
FIELD STUDIES ON THE FORAGING POPULATIONS AND CASTECOMPOSITION OF SAND SUBTERRANEAN TERMITE Psammotermes hybostoma (DESNEUX) IN EL-KONOOZ REGION, QENA GOVERNORATE Mohanny, K. M. ${ }^{1}$ and H. M. Ahmed ${ }^{2}$ 1- Plant Protection Dept., Fac. Agric., South Valley Univ., Qena, Egypt. 2-Plant Protection Res. Institute, Agric Res. Center., Cairo, Egypt.
}

\begin{abstract}
The obtained data from the used Poly Vinyl Chloride is a sermo plastic polymer (P.V.C.) traps which contained the corrugated card board represented the food source of subterranean termite, revealed that, the foraging population mostly differs according to season of year. Where, the minimum number of foraging population occurred in January.(1676) individuals. While, the maximum one were represented two peaks (9644 and 12357) individuals during April and August. The foraging population was decreased thought out May and June then decline in July then decreased gradually started from September to reach December. In general, 70913 individuals were collected from $280 \mathrm{~m}^{2}$ all over the year with an average of 21.1 individuals $/ \mathrm{m}^{2}$ or 88641.24 individuals as estimated number / feddan. The general average of caste composition were $77.62,13.96,4.50$ and $3.91 \%$ for workers, nymphs, Soldiers and winged adults, respectively. The total number of workers and soldiers were 58238 individuals. The total number of soldiers were 3193 represented $57.82 \%$ of all individuals. These numbers were collected from 235 P.V.C. traps represented 247.82 individuals per trap.
\end{abstract}

Keywords: Caste composition, population, foraging, Subterranean termites, traps.

\section{INTRODUCTION}

Ecological studies on the subterranean termites in arid regions are scares. The absolute density of subterranean termite populations in any particular habitat had not been reliably. Relative density, caste composition and foraging activity of subterranean termites have been studied by different methods, wooden stakes and wood blocks (Jones et al., 1990), toilet paper rolls (Lafage et al., 1973 and Said 1979) corrugated card board rolls (Lafage et al., 1983; El-Sebay, 1991; Ahmed, 2003 and El-Bassyouni,2001). Sand subterranean termite, Psammotermes hybostoma (Desneux) (Fam. Rhinotermitidae) is considered as a great economic importance in Egypt. It is cause a great damage to the rural buildings constricted with mud bricks as well as furniture and farmed wood within new buildings (Ahmed, 2008). This species is a widely dispersed all over the two sides of the River Nile and all Oases in both Eastern and Western deserts (Rizk et al,. 1985). Such methods which carried out in the same arid grass land have given a good results such as Saudi Arabi (Badawi et al., 1985) and in Egypt ( Hosny and Said, 1980). Qena Governorate is one of the most infested localities with subterranean termites. The present investigation is an attempt to study the foraging populations and caste composition for this species under Qena conditions. 


\section{MATERIALS AND METHODS}

Experiments were carried out in El-Konooz region, Qena Governorate from January 2009 to December 2009. The method devised to observe foraging population involved declining the dead wood from ground, where, all superficial and partially buried dead debris were removed from chosen area $\left(280 \mathrm{~m}^{2}\right)$ to prevent any nutrient interferences with the applied traps. Forty rolls of corrugated card board were prepared in the laboratory of Termite research in Plant Protection Research Institute where wrapped in roll shape $(10 \mathrm{~cm}$ high and $5-7 \mathrm{~cm}$ in diameter). Each roll of corrugated card board was placed inside perforated Poly Vinyl Chloride P.V.C. can (12 cm high and 5-7 $\mathrm{cm}$ in diameter) and sent to the experimental area .Tarps were distributed all over the area and arranged as 4 columns and 10 rows with $2 \mathrm{~m}$ intervals between each ones. Traps were wetted with water and closed with plastic cover before buried in holes $(12 \mathrm{~cm}$ depth in soil, the plastic cover of traps was appeared at the same level of soil surface and numbered for a marking sign of traps. Rolls of corrugated card board were served as food source of cellulose material and humidity which attracted the subterranean termite to the soil surface. To check for subterranean termite foraging population, each trap was removed form its hole, shaken into a plastic container to remove all individuals of subterranean termite handing to the bottom and inside of the trap and transferred to the laboratory in Plant Protection Department, Faculty of Agriculture, South Valley University. Individuals of subterranean termite were counted by using a fine brush, sorted into castes and identified. Each roll trap was then placed back to its hole, severely attacked traps were replaced by new ones. After month of collecting insects was kept for each trap involved the number of workers, nymphs, soldiers, and winged adults and the average number of soldiers per 100 workers were calculated. (Solders / Workers ratio).

\section{RESULTS AND DISCUSSION}

Data in Table (1) and Fig (1) show that, the foraging populations of sand subterranean termite, $P$. hybostoma increased gradually from Jan. and its peak ( 9644 individuals) in April then started decline during May and Jun, then increased again from July to reach the highest peak (12357 individuals) in August, then declined gradually during the remaining months. Ghoniemy et al., (1999) in El-fayoum, found that, the foraging activity of Anacanthotermes ochraceus (Burmeicter) increased gradually from January to reach its peak (1289 individuals) in April then decreased sharply to disappear in June and increased again in the subsequent two months, decreased in September then increased gradually during the remaining months. El-Bassyouni (2001) in Ismailia, mentioned that the largest individuals of foraged workers of $P$. hybostoma were during winter season, while the least one was during summer season. Ahmed (2007) stated that the population activity of $P$. hybostoma in Nubaria region had three peaks. The highest peak was in March with (3745 individuals). The moderate peak was in October with (2687 
individuals) and the lowest peak was in May with (2492 individuals). Data in Table (1) showed that, in general (70913) individuals were collected from $\left(280 \mathrm{~m}^{2}\right)$ all over the year with an average of 21.1 individuals $/ \mathrm{m}^{2}$ or (88641.24) individuals as estimated number / feddan. El-Sebay (1993) found that 158984 individuals of $A$. ochraceus were collected from $936 \mathrm{~m} 2$ during the year with an average (14.2) termite $/ \mathrm{m}^{2}$ or (59448.2) termite / feddan. Ahmed (2003) mentioned that, 169538 individuals was collected from 30 traps of the experimental area $250 \mathrm{~m}^{2}$ all over the year with an average 678.33 individuals $/ \mathrm{m}^{2}$ or 2848994 individuals as estimated number / feddan .According to Table (1) and Fig.(2), the general average of caste composition were $77.62,13.96,4.50$ and $3.91 \%$ for workers, nymphs, soldiers and winged adults respectively. The percentage was fluctuated through out the year, the highest percentage of workers 85.02 occurred during October and followed by $84.18 \%$ during March, while the least percentage was $68.41 \%$ during August .The highest percentage of nymphs $19.63 \%$ during September and followed by $19.09 \%$ during August, while the least percentage was $7.55 \%$ during May. The highest percentage of soldiers $9.36 \%$ occurred during December and followed by $7.34 \%$ during January, while the least percentage was 3.57\% during May. The highest percentage of winged adults $7.89 \%$ occurred during August and followed by $6.64 \%$ during May, while the least percentage was $0.0 \%$ through out Jun and July. Ahmed (2003) found that, the cast composition of $A$. ochraceus was 71.32, 28.02, 0.56 and 3.91 $\%$ for workers, nymphs, soldiers and winged adults, respectively.

Table (1): Number and percentage of Foraging population of sand subterranean termite,P.hybostoma from January 2009 to December 2009 at El-Konooz region Qena Governorate.

\begin{tabular}{|l|c|c|c|c|c|c|c|c|c|c|}
\hline \multirow{3}{*}{$\begin{array}{c}\text { Inspection } \\
\text { date }\end{array}$} & \multicolumn{6}{|c|}{\begin{tabular}{c} 
Number of foraged subterranean termite P. hybostoma \\
\cline { 2 - 11 }
\end{tabular}} & \begin{tabular}{c} 
Caste \\
\cline { 2 - 11 }
\end{tabular} & $\begin{array}{c}\text { Nomphs } \\
\text { caste }\end{array}$ & $\begin{array}{c}\text { Soldiers } \\
\text { caste }\end{array}$ & \multicolumn{2}{c|}{$\begin{array}{c}\text { Winged } \\
\text { adults }\end{array}$} & \multicolumn{2}{|c|}{ Total } \\
\hline January & 1286 & 76.73 & 214 & 12.76 & 123 & 7.37 & 53 & 3.16 & 1676 & 2.36 \\
\hline February & 2129 & 77.81 & 369 & 13.36 & 119 & 4.31 & 145 & 5.24 & 2762 & 3.89 \\
\hline March & 5482 & 84.18 & 612 & 9.39 & 253 & 3.88 & 165 & 2.53 & 6512 & 9.18 \\
\hline April & 7641 & 79.23 & 1285 & 13.32 & 427 & 4.43 & 291 & 3.01 & 9644 & 13.59 \\
\hline May & 4527 & 82.21 & 416 & 7.55 & 197 & 3.57 & 366 & 6.64 & 5506 & 7.76 \\
\hline June & 3180 & 79.95 & 593 & 14.91 & 204 & 5.13 & 0 & 0.0 & 3977 & 5.61 \\
\hline July & 6926 & 81.79 & 1146 & 13.53 & 396 & 4.67 & 0 & 0.0 & 8468 & 11.94 \\
\hline August & 8453 & 68.41 & 2360 & 19.09 & 569 & 4.60 & 975 & 7.89 & 12357 & 17.42 \\
\hline September & 7198 & 71.26 & 1983 & 19.63 & 373 & 3.69 & 546 & 5.41 & 10100 & 14.24 \\
\hline October & 4375 & 85.02 & 439 & 8.53 & 218 & 4.24 & 114 & 2.21 & 5146 & 7.25 \\
\hline November & 2358 & 82.36 & 297 & 10.37 & 136 & 4.75 & 72 & 2.51 & 2863 & 4.03 \\
\hline December & 1490 & 78.33 & 189 & 9.94 & 178 & 9.36 & 45 & 2.36 & 1902 & 2.68 \\
\hline Total & $\mathbf{5 5 0 4 5}$ & $\mathbf{7 7 . 6 2}$ & $\mathbf{9 9 0 3}$ & $\mathbf{1 3 . 9 6}$ & $\mathbf{3 1 9 3}$ & $\mathbf{4 . 5 0}$ & $\mathbf{2 7 7 2}$ & $\mathbf{3 . 9 1}$ & $\mathbf{7 0 9 1 3}$ & \\
\hline
\end{tabular}




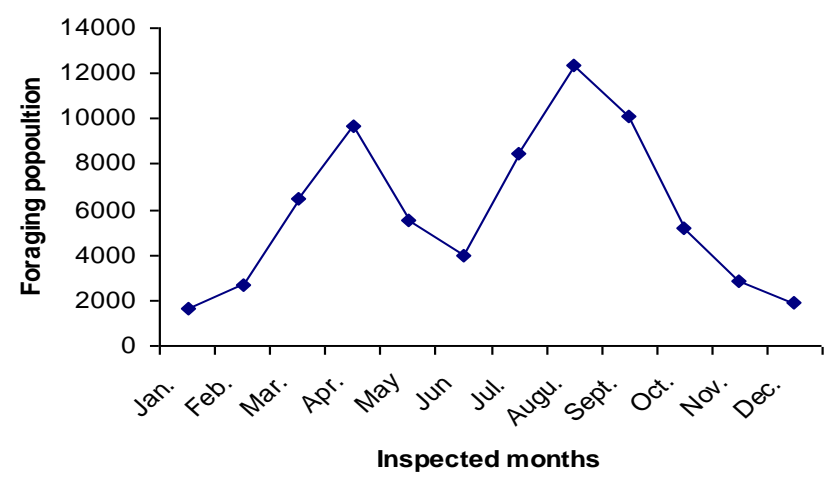

Fig. (1): Foraging population of sand subterranbean termite, P.hybostoma at El- Konooz region Qena Governorate.

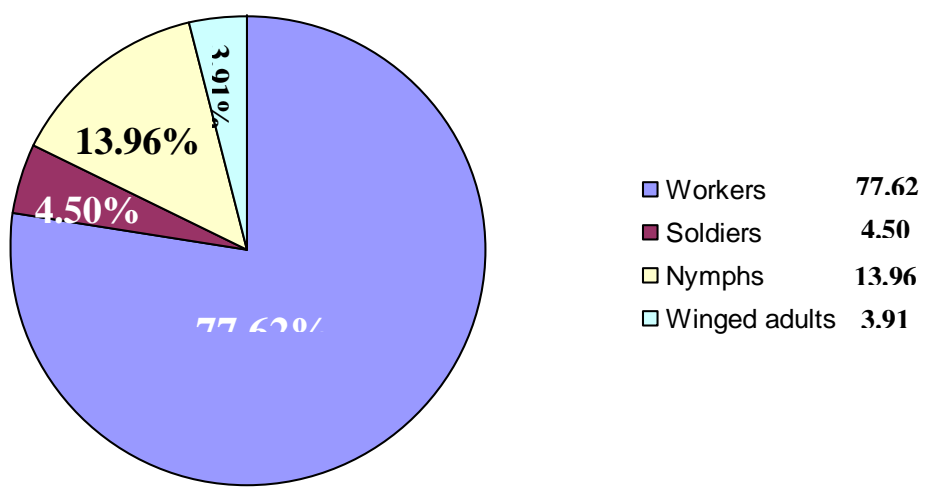

Fig. (2): Ratio of caste composition of P. hybostoma at El-Konooz region, Qena Governorate from January to December 2009.

The obtained data in Table (2) showed that the total number of workers and soldiers were 58238 individuals, The total number of soldiers were 3193 represented $57.82 \%$ of all individuals. These numbers were collected from 235 p.v.c. traps represented $247.82 \%$ individuals per trap. The number of individuals termite per trap in this study was higher than those recorded previously by Badawi et al. (1985) who found that, the ratios of $26.4 \%$ and $16.4 \%$ were recorded for Amitermes sp. While the lower ratio of $6.2 \%$ was recorded for Anacanthotermes sp. Ahmed (2008) showed that, the ratio of soldiers $/ 1000$ worker of P.hybostoma reached $14.20 \%$ and $13.47 \%$ in two regions. 
Table (2): Dispersal, number of individuals termite per trap and the ratio of soldiers $/ 1000$ worker of P.hybostoma during January to December 2009.

\begin{tabular}{|l|c|c|c|c|c|}
\hline $\begin{array}{c}\text { Subterranean } \\
\text { termite Species }\end{array}$ & $\begin{array}{c}\text { Number of } \\
\text { Workers \& } \\
\text { Soldiers }\end{array}$ & $\begin{array}{c}\text { Number of } \\
\text { Soldiers }\end{array}$ & $\begin{array}{c}\text { Number of } \\
\text { attracted } \\
\text { traps }\end{array}$ & $\begin{array}{c}\text { Subterranean } \\
\text { termite } \\
\text { individuals per } \\
\text { trap }\end{array}$ & $\begin{array}{c}\text { Soldiers } \\
/ 1000 \\
\text { Workers }\end{array}$ \\
\hline$P$. hybostoma & 58238 & 3193 & 235 & 247.82 & 57.82 \\
\hline
\end{tabular}

\section{REFERENCES}

Ahmed, H.M. (2003). Ecological and control studies on subterranean termites under Fayoum condtions. Ph.D. Thesis Fac. Agric. Fayoum, Cairo University, 148

Ahmed, H.M. (2007). Relative abundance and foraging activity of subterranean termites in olive plantations in Nubaria region, El-Behera Governorate. Bull. Fac. Agric., Cairo Univ., 58 (4): 280 -285.

Ahmed, H.M. (2008). Distribution and damage assessment of subterranean termites with refrence to foraging behaviour and population fluctuation at El -Giza Governorate. Alx. J. Res., 53 (1): 55 - 62.

Badawi, A.; Faragalla, A.A.; Dabbour, A. and Mostafa, S.A.S. (1985). Studies on the termites problem in Saudi Arabia, scientific Research Division, king Abdel-Aziz Univ., Saudi Arabia, Z.ang. Entomol., (5): 99-105.

El-Bassyouni, A.R. (2001). A study on the ecology and biological control of subterranean termites. M.sc. Thesis, Fac. Agric. Al-Azhar Univ., 145.

El-Sebay, Y. (1991). Amodified trap for El-Sebay subterranean termite. Fourth Arab Congress of Plant Protec. Cairo. 1-5. Dec., 1991: 245247.

El-Sebay, Y. (1993). Ecological studies on the harvester termites Anacanthotermes ochraceus (Burm.) in Egypt. Bull. Soc. Ent. Egypt, (47): 48-54.

Ghoniemy, H. A.; Mostafa, F. F.; El-Sebay, Y. and Ahmed, H. M. (1999). Ecological and control studies of harvester subterranean termite Anacanthotermes ochraceus (Burm) at Fayoum Governorate. Menofiya J. of Agric. Res., 24 (2): 727-740.

Hosny M.M. and Said W.A.(1980). Serten ecological aspect of the subterranean termites Anacanthotermes ochraceus (Burmeicter) in Egypt. Sociobiology, (5):133 -146.

Jones, S.C. (1990). Delineation and colony size of the desert subterranean termite Heterotermes aureus (Snyder) [Isoptera: Rhinotermitidae]. Foraging territories in asonoran desert grass land. Environ. Entomol., 19(4): 1047-1054

Lafage, J. P.; Nutting, W. L. and Haverty, M. I. (1973). Desert subterranean termites a method for studying foraging behaviour. Environ. Entomol., (2): 954-956.

Lafage, J. P.; S., N.Y.; Jones, M.J. and Esenther, R. (1983). A rapid method for collecting large numbers of subterranean termites from wood. Sociobiolgy, (7): 305 - 309. 
Rizk, M.M.; El-Sayed, A.R.; Ali , A.M. and Eraky, S.A. (1985). Flight activity and annual caste fluctuation of sand termite Psammotermes hybostoma (Desneux) I western desert Egypt. Assuit. J. Agric., 16 (2): $137-148$.

Said, W. A. (1979). Ecological and toxicological studies on Fam. Hodotermitidae M.Sc. Thesis Fac. of Agric. Ain Shams Univ.,128.

دراسات حقليه على تعداد السروح و تركيب المستعمره لنمل الرمـال تحت الأرضى Psammotermes hybostoma (Deseneux)

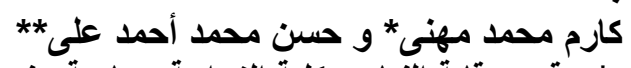

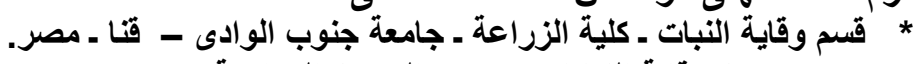

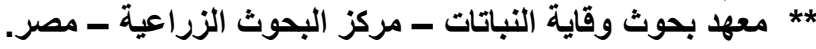

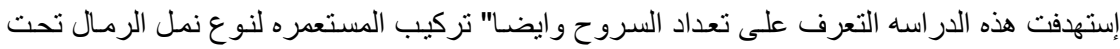

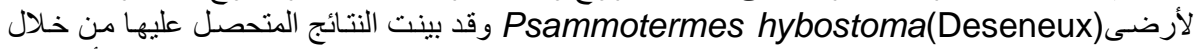

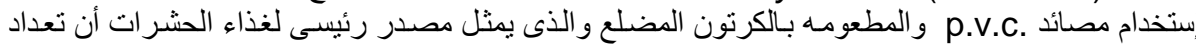

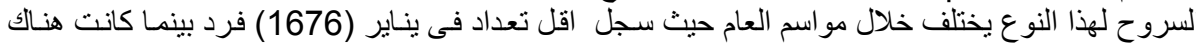

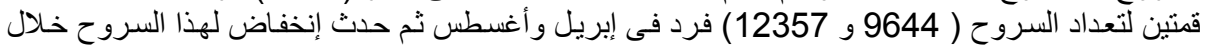

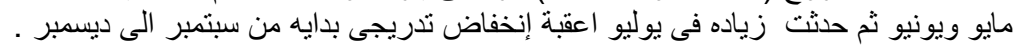

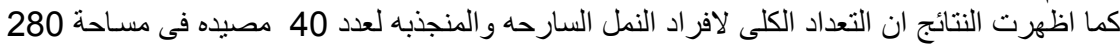

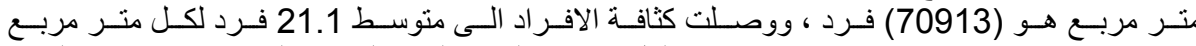

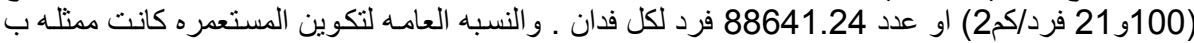

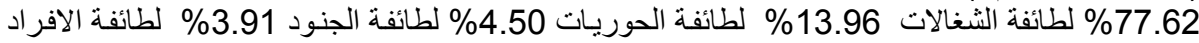

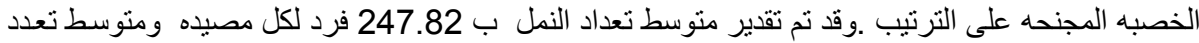
الجنود لكل 1000 شغاله يمثل 57.82 جندى .

كلية الزراعة - جامعة المنصورة كلية الزراعة - جامعة الفيوم
قام بتحكيم البحث أ.د / أدادل حسن عبد البحت السلام

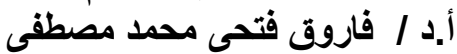

